\title{
Use of Regular Vaccination Schedule in Hemodialysis Patients and Awareness
}

\author{
Hemodiyaliz Hastalarında Düzenli Aşı Takvimi \\ Kullanımı ve Farkındalıkları
}

\author{
Eylem TOPBAŞ ${ }^{1}$, Buğra Burak TURAN ${ }^{2}$, Hakan BAY ${ }^{3}$, Ahmet Hüdai EMİR $^{4}$, Umut ÇITLAK $^{5}$, \\ Tuğba KAVALALI ERDOĞAN ${ }^{6}$
}

${ }^{I}$ Dr. Öğr. Üyesi, Amasya Üniversitesi, Sağllk Bilimleri Fakültesi, Hemşirelik Bölümü. Amasya, Türkiye

${ }^{2}$ Hemşire, Erzurum Bölge Eğitim Araştırma Hastanesi. Erzurum, Türkiye

${ }^{3}$ Hemşire, Bülent Ecevit Üniversitesi Eğitim ve Araștırma Hastanesi. Zonguldak, Türkiye

${ }^{4}$ Ögrenci Hemşire, Amasya Üniversitesi, Sağllk Bilimleri Fakültesi, Hemşirelik Bölümü. Amasya, Türkiye

${ }^{5}$ Hemsirire, Cumhuriyet Üniversitesi Tıp Fakültesi Hastanesi. Sivas, Türkiye

${ }^{6}$ Araştırma Görevlisi, Ondokuz Mayıs Üniversitesi, Sağlık Bilimleri Fakültesi, Hemşirelik Bölümü. Samsun, Türkiye

* Bu çalışma 21-25 Ekim 2015 tarihleri arasında Antalya'da düzenlenen 25.Ulusal Nefroloji Hemşireliği Kongresi’nde poster bildiri olarak sunulmuş ve “Poster Bildiri Birincilik Ödülü” almıştır.

Geliş Tarihi: 14 Mayıs 2019

Kabul Tarihi: 02 Ocak 2020

\section{İletişim / Correspondence:}

Eylem TOPBAŞ

E-posta: eylem.topbas@gmail.com

\begin{abstract}
Aim: The aim of this study was to determine the extent of use of regular vaccination schedule, the extent of hepatitis $B$ vaccinations before dialysis and the awareness of patients on this matter in hemodialysis patients.

Method: The population of this descriptive study consisted of patients treated in a total of 26 centers in six provinces $(n=353)$, and patients who were willing to participate in the study $(\mathrm{n}=246)$ comprised the sample.

Results: Mean age of the patients was $57.26 \pm 14$, and $35.4 \%$ had an influenza+ hepatitis B vaccine, $35 \%$ only had a hepatitis-B vaccine, and $56.9 \%$ had a hepatitis B vaccine 1-6 years before starting to receive dialysis. There was a statistically significant difference between the status of getting vaccinated regularly, age, the status of having received training on vaccination, the status of knowing which vaccines to have $(\mathrm{p}<0.05)$. There was a statistically significant difference between the status of having hepatitis B vaccine before starting dialysis and the status of having received training on vaccination, and the person who gave the training $(\mathrm{p}<0.05)$.
\end{abstract}

Conclusion: It was determined that the rate of vaccination of patients from the group who received training on vaccines from a nurse and the rate of patients who had Hepatitis B vaccine before starting dialysis were high.

Keywords: Vaccination Schedule; Hemodialysis; Patient; Nurse

Özet

Amaç: Hemodiyaliz hastalarında düzenli aşı takviminin kullanılma durumunun, diyaliz öncesi hepatit B aşısını yaptırma durumunun ve hastaların bu konudaki farkındalığının belirlenmesi amacı ile yapılmıştır.

Metot: Tanımlayıcı nitelikte olan bu çalışmanın evrenini altı ilde bulunan toplam 26 merkezde tedavi gören hastalar $(\mathrm{n}=353)$, örneklemini ise araştırmaya katılmaya gönüllü hastalar ( $\mathrm{n}=246$ ) oluşturmuş̧tur. Veriler "kişisel bilgi formu" kullanılarak yüz yüze görüşme yöntemi ile elde edilmiştir. 


\begin{abstract}
Bulgular: Yaş ortalaması 57,26 \pm 14 olan hastaların, \%35,4'ünün grip + hepatit B aşısını yaptırdığ 1 , \%35'inin sadece hepatit-B aşısı yaptırdığı, \%56,9'unun ise hepatit B aşısını diyalize başlamadan 1-6 yıl önce yaptırdığı tespit edilmiştir. Hastaların düzenli aş1 yaptırma durumu ile yaş, aş1 yaptırma konusunda eğitim alma durumu, hangi aşıları mutlaka yapılmasını bilme durumu arasında istatistiksel açıdan anlamlı farklılık vardır $(\mathrm{p}<0.05)$. Hepatit $\mathrm{B}$ aşısını diyalize başlamadan önce yaptırma durumu ile aşı konusunda eğitim alma durumu ve eğitimi kimden aldığı arasında istatistiksel açıdan anlamlı farklılık vardır $(\mathrm{p}<0.05)$. Sonuç: Aşılar konusunda hemşireden eğitim alan grubun aşı yaptırma oranının ve hepatit B aşısının diyalize başlamadan önce yaptırma oranlarının yüksek olduğu saptandı.
\end{abstract}

Anahtar Sözcükler: Aşı Takvimi; Hemodiyaliz; Hasta; Hemşire.

\section{INTRODUCTION}

Cellular and humoral immune response is impaired in patients with chronic renal failure (1). Therefore, they are at a high risk of developing secondary infections. In literature it is stated that "Infections are responsible for $\% 8$ of the deaths for dialysis patients" (2). Pneumonia, hepatitis and influenza infections, which may cause significant rates of morbidity and mortality, can be partially or completely prevented by vaccination (1). Vaccination is a cost-effective application (2). Hemodialysis units are risky centers for transmission of viral and bacterial infections for both patients and health care personnel working in these centers. Factors that increase the risk of infection include blood transfusion, hemodialysis being an invasive procedure, frequent patient visits to the hospital for dialysis, contaminated hands and surfaces during dialysis, and contaminated devices. In literature, "It is stated that hepatitis B virus may remain stable and active on environmental surfaces for at least 7 days" (2). Vaccination is therefore important for preventing Hepatitis B. Educations should be organized to increase awareness of both patients and medical staff on vaccines.

In literature, it is stated that besides educations on vaccines, seroconversion rates of hepatitis $B$ are also affected by age, gender, duration of dialysis, hemofiltration, vitamin D deficiency, high-dose erythropoietin, Levamisole supplement, renal replacement therapy option, systemic diseases, serum albumin level being $<3.5 \mathrm{~g} / \mathrm{dl}$, obesity and stage of chronic kidney disease (2-5). In literature, it is emphasized that "Hepatitis $B$ vaccination, stringent precautions in all dialysis centres, intense health education to both patients and medical staff will be beneficial to lower the seroconversion and high financial burden on end-stage renal disease patients" (6).

In addition, it is recommended by the British guidelines and US that patients are administered Fendrix $20 \mathrm{mg}$ and two Engerix-B $20 \mathrm{mg}$ in a 4 dose schedule $(0,1,2$, and 6 months $)$ in 1 or 2 injections; Recombivax $\mathrm{HB}, 40 \mu \mathrm{g} / \mathrm{mL}$ and HBvaxPRO $40 \mathrm{mg}$ are administered in a 3 dose schedule (0, 1 and 6 months) 1 injection. Booster dose is needed if the annual anti-Hbs titer is $<10$ $\mathrm{mIU} / \mathrm{mL}(2,7,8)$.

Influenza virus is another infectious disease which causes an increase in morbidity and mortality rates. Thus, many advisory boards state that seasonal flu vaccine is required once a year for all chronic diseases and there is no need for a booster during the year (2).

A study by Kosmadakis et al. states that Sarnak and Jaber (2001) indicated that "Patients on dialysis have a high incidence of respiratory infections with mortality rates up to 16-fold higher compared to the general population" (2). A study by Kosmadakis et al. states that Tomczyk et al. (2014), Portoles-Perez et al. (2014), Haute Conseil (2017) indicated that, "All adults aged $\geq 65$ should receive PCS-13 followed by a PPSV-23 6-12 months later. Congenital or acquired immune-deficient adults aged $\geq 19$ should receive a booster dose of PPV-23 at least 
5 years later. $P P V$-23-vaccinated people should receive $P C V-13$ at least 1 year after the PPSV-23 dose" (25). Kosmadakis et al. (2018) stated/ indicated that: According to recommendations from the United States, Spain, and France from 2013-2014, PCV-13 followed by a PPSV-23 6-12 months later is recommended for all adults $\geq 65$ years old, and in congenital or acquired immunedeficient adults of $\geq 19$ years with a booster dose of PPSV-23 at least 5 years later. In PPSV-23vaccinated persons, PCV-13 should be administered at least one year after the PPSV-23 dose. Coadministration with the inactivated influenza vaccine is not contraindicated; the combination may even have synergistic beneficial effects (2). The recommended vaccines for dialysis patients are haemophilus influenza, hepatitis B and pneumococcal vaccines (9). Therefore, it is critical to include patients in the vaccination schedule before starting dialysis. All vaccines for dialysis patients are shown in Table 1.
Previous studies in the literature reported the incidence of hepatitis in hemodialysis patients (12), however, there is no study that investigated whether the patients have received training on vaccination and the effect on immunization rate of the person who has provided such training. Therefore, this study was aimed at revealing the extent of use of regular vaccination schedule, the extent of hepatitis $\mathrm{B}$ vaccination before dialysis and the awareness of patients on this matter in hemodialysis patients.

\section{METHOD}

Selection of Population and Sample: The population of this descriptive study consisted of patients treated in a total of 26 centers in six provinces $(\mathrm{A}, \mathrm{B}, \mathrm{C}, \mathrm{D}, \mathrm{E}, \mathrm{F})(\mathrm{n}=353)$, and patients who were willing to participate in the study $(\mathrm{n}=246)$ comprised the sample. The data was collected by interview method using Personal Information Form prepared by the researchers between January and February 2015.

Table 1. Vaccines Recommended for Dialysis Patient

\begin{tabular}{|c|c|c|c|c|}
\hline Vaccine & Age & Dose & $\begin{array}{l}\text { Vaccination schedule/ route } \\
\text { of administration }\end{array}$ & Booster Doses \\
\hline Hepatitis B & $\begin{array}{l}\geq 20 \text { years } \\
<20 \text { years }\end{array}$ & $\begin{array}{l}40 \mathrm{mcg} \\
10 \mathrm{mcg}\end{array}$ & $\begin{array}{l}0,1,2,6 \text { months / IM } \\
0,1,6 \text { months / IM }\end{array}$ & $\begin{array}{l}\text { When anti- } \\
\mathrm{HBs}<10 \mathrm{Ul} / 1\end{array}$ \\
\hline Influenza & $\begin{array}{l}3-8 \text { years } \\
9-12 \text { years } \\
>12 \text { years }\end{array}$ & $15 \mu \mathrm{g}$ & Each year / IM & No \\
\hline $\begin{array}{l}\text { Pneumococcal } \\
\text { *PCV13 } \\
* * \text { PPSV23 }\end{array}$ & & \multicolumn{3}{|c|}{$\begin{array}{l}\text { *8+ weeks later give PPSV23, then } 5 \text { years later give a second dose } \\
\text { of PPSV23 } \\
* * 1 \text { year later give PCV13 and } 5 \text { years after initial PPSV23 vaccine } \\
\text { give second dose of PPSV23 }\end{array}$} \\
\hline Hepatit A & $>17$ years & $1440 \mathrm{U}$ & $0,6,12$ months / IM & No \\
\hline Measles, mumps, rubella & $>18$ & $0,5 \mathrm{ml}$ & One single dose / $\mathrm{SC}$ & No \\
\hline Varicella & $1-12$ years & $0.5 \mathrm{ml}$ & One single dose / SC & No \\
\hline Inactivated poliovirus & $<18$ years & $0.5 \mathrm{ml}$ & $\begin{array}{l}\text { Three doses with an interval of } \\
1-2 \text { months }\end{array}$ & $\begin{array}{l}\text { No (revaccination } \\
\text { one year after the } \\
\text { third dose) }\end{array}$ \\
\hline $\begin{array}{l}\text { Diphtheria and tetanus } \\
\text { toxoids }\end{array}$ & 7 years & $0.5 \mathrm{ml}$ & Three doses / IM & No \\
\hline
\end{tabular}

IM: Intramuscular, SC: Subcutaneous

References: Krueger, K. M., Ison, M. G., \& Ghossein, C. (2019). Practical Guide to Vaccination in All Stages of CKD, Including Patients Treated by Dialysis or Kidney Transplantation. American Journal of Kidney Diseases. doi:10.1053/ j.ajkd.2019.06.014

Guidelines for vaccination in patients with chronic kidney disease. (2016). Indian Journal of Nephrology, 26(Suppl 1), S15S18. 


\section{Data Collection Tool}

Personal Information Form: This form consisted of three parts. It comprises a total of 19 questions, including eight questions about demographic data of the patients in part one (gender, age, occupation, educational status, income level, work status, social security and place of residence), five questions about diseasespecific characteristics of the patients in part two (length of chronic disease, duration of hemodialysis, frequency of hemodialysis, primary disease causing chronic renal failure, whether s/he had extra dialysis over the last one month), six questions about vaccinations in part three (the status of getting vaccinated regularly, which vaccines $s /$ he regularly has, whether $\mathrm{s} / \mathrm{he}$ knows which vaccines dialysis patients should definitely have, whether $\mathrm{s} /$ he has received training on getting vaccinated, from whom $\mathrm{s} / \mathrm{he}$ has received training on getting vaccinated, whether s/he had hepatitis B vaccine before/after starting dialysis).

\section{ETHICAL CONSIDERATIONS}

The human rights Helsinki Declaration was abided by throughout the study. All ethical permissions for the study were obtained in written form from the Association of Public Hospitals Secretary General of all cities and relevant hospitals (Ref: A: 15835813/771; B: 80440342/770; C: $80440342 / 770 ; \quad$ D: 52918460/773.99, E: $49715540.00 .00, \quad$ F: 30640013-1175).

\section{RESULTS}

\section{Demographic and disease-specific} characteristics of patients: The mean age of the patients was $57.26 \pm 60,51.2 \%$ were male, $72 \%$ were married, $45.1 \%$ were literate, and $45.1 \%$ were housewives. The median duration of having hemodialysis of the patients was four years. $94.3 \%$ of the patients received dialysis treatment three times a week and the primary disease of $36.6 \%$ of the patients was hypertension.

\section{Characteristics of patients related to the status} of getting vaccinated and their knowledge status: Considering the type of vaccines the patients had, $35.4 \%$ of the patients had an influenza + hepatitis B vaccine, and $35 \%$ only had a hepatitis-B vaccine. The rate of patients who had influenza, hepatitis B and pneumococcal vaccines, which dialysis patients should definitely have, was $1.2 \%$. $71.5 \%$ of the patients did not know which vaccines s/he should definitely have and $68.7 \%$ did not receive training on vaccination, and $56.9 \%$ had a hepatitis B vaccine 1-6 years before starting dialysis.

There was a statistically significant difference between the status of getting vaccinated regularly, age, the status of having received training on vaccination, the status of knowing which vaccines to have $(p<0.05)$. The rate of vaccination of those who received training was higher than the other group (Table 2).

No statistically significant difference was found between the status of getting vaccinated regularly and gender, marital status, duration of hemodialysis and between the status of knowledge of the vaccines $\mathrm{s} /$ he should definitely have and age, gender, occupation and marital status $(p>0.05)$. There was a statistically significant difference between educational status and the status of knowledge of which vaccine to have regularly and the status of getting vaccinated regularly $(p<0.05)$. The level of knowledge and vaccination rates of the primary school group were higher compared to the other groups.

There was no statistically difference was identified between the person who provided training about vaccination and the status of getting vaccinated regularly ( $>0.05$ ) (Table 2). The rate of vaccination of patients who received training about vaccination from a nurse was higher. 
Table 2. The Relationship between the Status of Having Received Training on Vaccination and Getting Vaccinated Regularly

\begin{tabular}{|c|c|c|c|c|c|}
\hline & & & \multicolumn{2}{|c|}{ Do you regularly get vaccinated? } & \multirow{2}{*}{ Total } \\
\hline & & & Yes & No & \\
\hline \multirow{2}{*}{$\begin{array}{l}\text { Have you received training on } \\
\text { vaccination? }\end{array}$} & Yes & n (\%) & $73(94.8 \%)$ & $4(5.2 \%)$ & $77(100.0 \%)$ \\
\hline & No & n (\%) & $131(77.5 \%)$ & $38(22.5 \%)$ & $169(100.0 \%)$ \\
\hline \multicolumn{2}{|l|}{ Total } & n (\%) & $204(82.9 \%)$ & $42(17.1 \%)$ & $246(100.0 \%)$ \\
\hline \multicolumn{6}{|l|}{$x^{2}: 0.002 \quad p>0.05$} \\
\hline
\end{tabular}

Table 3. The relationship between the person who provided training about vaccination and the status of getting vaccinated regularly

\begin{tabular}{|c|c|c|c|c|c|}
\hline & & & \multicolumn{2}{|c|}{$\begin{array}{l}\text { Do you regularly get } \\
\text { vaccinated? }\end{array}$} & \multirow[t]{2}{*}{ Total } \\
\hline & & & Yes & No & \\
\hline \multirow{2}{*}{$\begin{array}{l}\text { From whom did you } \\
\text { receive the training? }\end{array}$} & Hemodialysis Nurse & n (\%) & $62(95.4 \%)$ & $3(4.6 \%)$ & $65(100.0 \%)$ \\
\hline & Hemodialysis Doctor & n (\%) & $11(91.7 \%)$ & $1(8.3 \%)$ & $12(100.0 \%)$ \\
\hline \multicolumn{2}{|l|}{ Total } & n (\%) & $73(94.8 \%)$ & $4(5.5 \%)$ & $77(100 . \%)$ \\
\hline$X^{2}:$ Fisher's Exact & \multicolumn{5}{|c|}{ Cramer's V: $0.061 ; p=0.061>0.05$} \\
\hline
\end{tabular}

\section{DISCUSSION}

Vaccination is important in hemodialysis patients as it reduces hepatitis infection, pneumococcal and influenza related diseases and the financial burden of these diseases. Furthermore, vaccinations rates are and should be an indicator of quality control for dialysis units (2). Viral hepatitis is considered to be an important problem in hemodialysis patients. Because $1.9 \%$ of the deaths in this population are caused by viral hepatitis diseases (13). According to the registry report for 2017 of Turkish Society of Nephrology, the rates of HBsAg $(+)$ and Anti$\mathrm{HCV}(+)$ were in the range of $11-5.6 \%$ and $21.3-$ $11.3 \%$, respectively in Turkey between the years 1997-2002, and the rates reported for 2017 were $2 \%$ for HBsAg $(+)$ and $1.6 \%$ for Anti-HCV $(+)$ (14). The decrease in these rates by year suggest that personnel training and patient training have been effective. In our study, the rate of patients who received training was higher compared to the other groups, which is in good agreement with the aforementioned statement. It is remarked about the timing of hepatitis B vaccine that early vaccination exposes patients to the risk of loss of immunity $(4,15-17)$.

Hepatitis vaccine is recommended in stage 4 $(\mathrm{GFR}<30 \mathrm{mmHg})$ chronic kidney disease $(2,18$,
19). "Patients with uremia who were vaccinated before they required dialysis have been shown to have higher seroprotection rates and antibody titers" (9). In our study, half of the patients in the sample group had hepatitis vaccine before starting dialysis, which is a desired practice. However, in order to increase this rate to $100 \%$ by training, hemodialysis nurses should continue to provide training on vaccination. In our study, the rate of vaccination of patients who received training from a hemodialysis nurse was high, which lends support to our opinion. As a result of a three-phased study which includes education phase, baseline assessment of vaccination rates, intervention, and a follow-up assessment of vaccination rates, it is stated that a general improvement on the vaccination rates was present (20).

Educations on vaccination may contribute to changing both patients' and medical staff's perspective on vaccines. Infectious diseases are the second most common causes of morbidity and mortality (after cardiovascular disease) in patients with CKD. Uremic toxins, nutritional deficiencies contribute to immune dysregulation, which are further complicated by renal replacement therapies. For this reason, we think that this education should be continuous. 


\section{CONCLUSION}

It is recommended that patients are given information about vaccinations before starting dialysis, that they have hepatitis $\mathrm{B}$ vaccines before starting dialysis, and that they should definitely have hepatitis B, influenza and pneumococcal vaccines, which they should definitely have, throughout hemodialysis treatment.

\section{REFERENCES}

1. Koşan C. The use of vaccines in chronic dialysis patients. AÜTD 2002; 34: 25-29.

2. Kosmadakis G, Albaret J, Correia EDC, Somda F, Aguilera D. Vaccination practices in dialysis patients: A narrative review. In Seminars in Dialysis 2018; 31(5): 507-518.

3. Erdoğdu Hİ, Atalay E, Gürsoy G, Canbakan B, Aktürk S, and et al. Factors affecting inadequate response to HBV vaccine in hemodialysis patients: northeast anatolia survey with six hemodialysis centers. Clinical and experimental nephrology 2019; 23(4): 530-536.

4. Dimitrov Y, Ducher M, Kribs M, Laurent G, Richter S, and et al. Variables linked to hepatitis B vaccination success in non-dialyzed chronic kidney disease patients: Use of a Bayesian model. Nephrologie \& Therapeutique 2019; 15(4): 215-219.

5. Fabrizi F, Dixit V, Messa P, Martin P. Meta-analysis: levamisole improves the immune response to hepatitis B vaccine in dialysis patients. Alimentary Pharmacology \& Therapeutics 2010; 32(6):756-762.

6. Masoodi I, Singh C, Wani IA, Wani MM, Ahmed TI, and et al. Sero conversion of viral hepatitis among end stage renal disease patients on hemodialysis in Kashmir: Results of a prospective study. Open Access Macedonian Journal of Medical Sciences 2019; 7(4): 587-93.

7. Geddes C, Lindley E, Duncan N. Renal Association Clinical Practice Guideline on prevention of blood borne virus infection in the renal unit. Nephron Clinical Practice 2011; 118(Suppl 1): c165-c188.

8. Guidelines for vaccinating kidney dialysis patients and patients with chronic kidney disease summarized from Recommendations of the Advisory Committee on Immunization Practices (ACIP), 2012. https://www.cdc.gov/vaccines/pubs/dialysis-guide-2012.pdf. Access Date: 01.10 .2019

9. Guideline for vaccinating kidney dialysis patients and patients with chronic kidney disease, (2015). https://www.cdc.gov/vaccines/pubs/downloads/dialysis-guide-2012.pdf.

10. Krueger KM, Ison MG, Ghossein C. Practical guide to vaccination in all stages of CKD, including patients treat,ed by dialysis or kidney transplantation. American Journal of Kidney Diseases 2019; XX(XX)):1-9 doi:10.1053/j.ajkd.2019.06.014 (In pres)

11. Guidelines for vaccination in patients with chronic kidney disease. Indian Journal of Nephrology 2016; 26(Suppl 1): $15-\mathrm{S} 18$.

12. Tosun S. The changing viral hepatitis epidemiology in our country. ANKEM Derg 2013; 27: 128-134.

13. Aghakhani A, Banifazl M, Velayati AA, Eslamifar A, Ramezani A. Occult Hepatitis B virus infection in hemodialysis patients: a concept for consideration. Ther Apher Dial 2012; 16(4): 328-33. doi: 10.1111/j.1744-9987.2012.01072.x.

14. Süleymanlar G, Ateş K, Seyahi N. Registry of the nephrology, dialysis and transplantation in Turkey Regisrty 2017. Miki Matbac1lık, 2018.

15. Chaves SS, Daniels D, Cooper BW, Malo-Schlegel S, Macarthur S, and et al. Immunogenicity of hepatitis B vaccine among hemodialysis patients: effect of revaccination of non-responders and duration of protection. Vaccine 2011; 29 -23.

16. Barraclough KA, Wiggins KJ, Hawley CM, van Eps CL, Mudge DW, and et al. Intradermal versus intramuscular hepatitis B vaccination in hemodialysis patients: a prospective open-label randomised controlled trial in nonresponders to primary vaccination. American Journal of Kidney Diseases 2009; 54: 95-103.

17. Tsouchnikas I, Dounousi E, Xanthopoulou K, Papakonstantinou S, Thomoglou V, et al. Loss of hepatitis B immunity in hemodialysis patients acquired either naturally or after vaccination. Clinical Nephrology 2007; 68(4): 228-34.

18. Topbaş E. Kronik böbrek hastalığının önemi, evreleri ve evrelere özgü bakımı. Nefroloji Hemşireliği Dergisi 2015; 10(1): 53-59.

19. Jenkins K, Mahon A. Haemodialysis, in: Chronic kidney disease. EDTNA/ERCA, 2008. pp111.

20. Duval L, George C, Hedrick N, Woodruff S, Kleinpeter MA. Network 13 partnership to improve the influenza, pneumococcal pneumonia, and hepatitis B vaccination rates among dialysis patients. Advances in Peritoneal Dialysis 2011; 27: 106-111. 